\title{
A revision of Ostodes (Euphorbiaceae) in Malesia
}

\author{
P.C. van Welzen ${ }^{1,2}$, E. Winkel ${ }^{1}$
}

Key words

Dimorphocalyx

Euphorbiaceae

Malesia

Ostodes

Paracroton

Trigonostemon

\begin{abstract}
The variability of Ostodes paniculata var. paniculata, the only representative of the genus in Malesia is described. The variety and the species have a disjunct distribution as they are found in India to Southern China and the Southeast Asian mainland, Sumatra and Java. The variability in leaf glands, domatia, sepals, and seeds shows geoclines. Depending on one's view the genus has two more varieties or species, both more hairy and occurring from $\mathrm{N}$ Thailand to China or in China only. Their nomenclature is provided, as is the nomenclature of the many excluded species, once part of a larger generic concept of Ostodes, but now mainly part of Dimorphocalyx and Paracroton. Typical for Ostodes are the red latex, the ovate, rather large serrate leaf blades with basally two raised glands, the paniculate inflorescences with relatively large flowers with petals and many (nearly) free stamens, and the large woody fruits
\end{abstract}

Published on 31 March 2015

\section{INTRODUCTION}

The small genus Ostodes was described by Blume in 1825 based on O. paniculata Blume. The genus occurs from India to Southern China and the Southeast Asian mainland, Sumatra and Java, but it is unknown for the Malay Peninsula. Over the course of time the number of species increased, but mainly with species now considered to be part of Dimorphocalyx Thwaites and Paracroton Miq. (formerly known as Fahrenheitia Rchb.f. \& Zoll.). Paracroton was revised for the Indian subcontinent by Balakrishnan \& Chakrabarty (1993) and they also explain why it should be Paracroton instead of the older name Fahrenheitia, because Fahrenheitia was described with doubt by Zollinger (1856). Paracroton has stellate hairs, which are absent in Ostodes, Dimorphocalyx, and the related Trigonostemon Blume. Ostodes has free to at most basally united stamens, but the inner ones of Dimorphocalyx and Trigonostemon are almost completely united (see Airy Shaw 1967).

Typical for Ostodes, besides the (almost) free stamens, are the red latex, the glands at the base of the leaf blades with between them a somewhat thickened midrib, the rather large woody fruits, the petals with hairs basally on the inside, and the typical disc glands in the staminate flowers.

Within Ostodes three species have been recognised, but this depends on how one values the differences. A fourth species, $O$. thyrsantha Pax (Pax \& Hoffmann 1911) is hereby considered as a synonym of $O$. katharinae, following the view of Chang (1982). Ostodes paniculata is the most common form throughout the distribution of the genus. Ostodes katharinae Pax (Pax \& Hoffmann 1911) and O. kuangii Y.T.Chang (Chang 1982) are only found in N Thailand and China or China only, respectively. Ostodes katharinae and $O$. kuangii are more hairy than O. paniculata, especially the inflorescences and calyces, whereas $\mathrm{O}$. $\mathrm{ku}$ angii has the most hairs, which are also present on the leaves. However, in N Thailand there are some specimens intermediate between $O$. paniculata and $O$. katharinae, and therefore the lat-

\footnotetext{
Naturalis Biodiversity Center, Botany, P.O. Box 9517, 2300 RA Leiden, The Netherlands; corresponding author e-mail: peter.vanwelzen@naturalis.nl.

2 Institute of Biology Leiden, Leiden University, P.O. Box 9505, 2300 RA Leiden, The Netherlands.
}

ter is often considered to be variety of $O$. paniculata instead of a species (O. paniculata Blume var. katharinae (Pax) Chakrab. \& N.P.Balakr.; Chakrabarty \& Balakrishnan 1985). This latter view is followed in the Flora of Thailand (Phattarahirankanok \& Chayamarit 2007) and by us. Neither O. katharinae nor $O$. kuangii are included in this treatment, and therefore, the species status of $O$. kuangii is not assessed.

Webster (1994) and Radcliffe-Smith (2001) placed Ostodes in subfamily Crotonoideae tribe Codiaeae. Müller (1865) divided Ostodes into two sections, section Euostodes Müll.Arg. (invalid name) and section Geloniastrum Müll.Arg. The latter is monotypic and only contains $O$. helferi Müll.Arg. as the type. Unfortunately, $O$. helferi appears to be an unidentified species of Popowia (Annonaceae) (Airy Shaw 1967). An infrageneric division is redundant for only two species.

\section{TAXONOMIC TREATMENT}

\section{Ostodes}

Ostodes Blume (1825) 619; Baill. (1858) 391; Miq. (1859) 383; Müll.Arg (1866) 1114; Kurz (1877) 403; Benth. (1880) 299; Hook.f. (1887) 400; Pax \& K.Hoffm. (1911) 17; Gagnep. (1925) 322; Pax \& K.Hoffm. (1931) 157; Backer \& Bakh.f. (1963) 493; Airy Shaw (1967) 411; (1972) 311; (1981) 334; Chakrab. \& N.P.Balakr. (1985, publ. 1987) 259; Grierson \& D.G.Long (1987) 795; G.L.Webster (1994) 105; Radcl.-Sm. (2001) 296; Phattar. \& Chayam. (2007) 460. — Ostodes Blume sect. Euostodes Müll.Arg. (1865) 214, nom. inval.; (1866) 1114. - Ostodes Blume sect. Desmostemon (Thwaites) Pax in Pax \& Hoffmann (1911) 18, nom. inval.; (1931) 157. Type: Ostodes paniculata Blume.

Shrubs to trees, dioecious (see note); branchlets with many leaf scars; red latex present. Indumentum of simple hairs, white, especially on young parts, caducous. Stipules small, very coriaceous, very early caducous, only present at end of branchlets. Leaves simple, alternate, mainly at end of branchlets; petiole indistinctly to distinctly pulvinate at both ends, apically often (especially on Java) with 2 glands (additional to those on blade base); blade symmetric, papery, base with two elevated (northern specimens) to shortly pedicellate (W Malesian specimens) glands near the midrib, these sometimes indistinct, midrib thickened basally, margin serrulate (northern specimens) to coarsely serrate (W Malesian specimens), teeth 


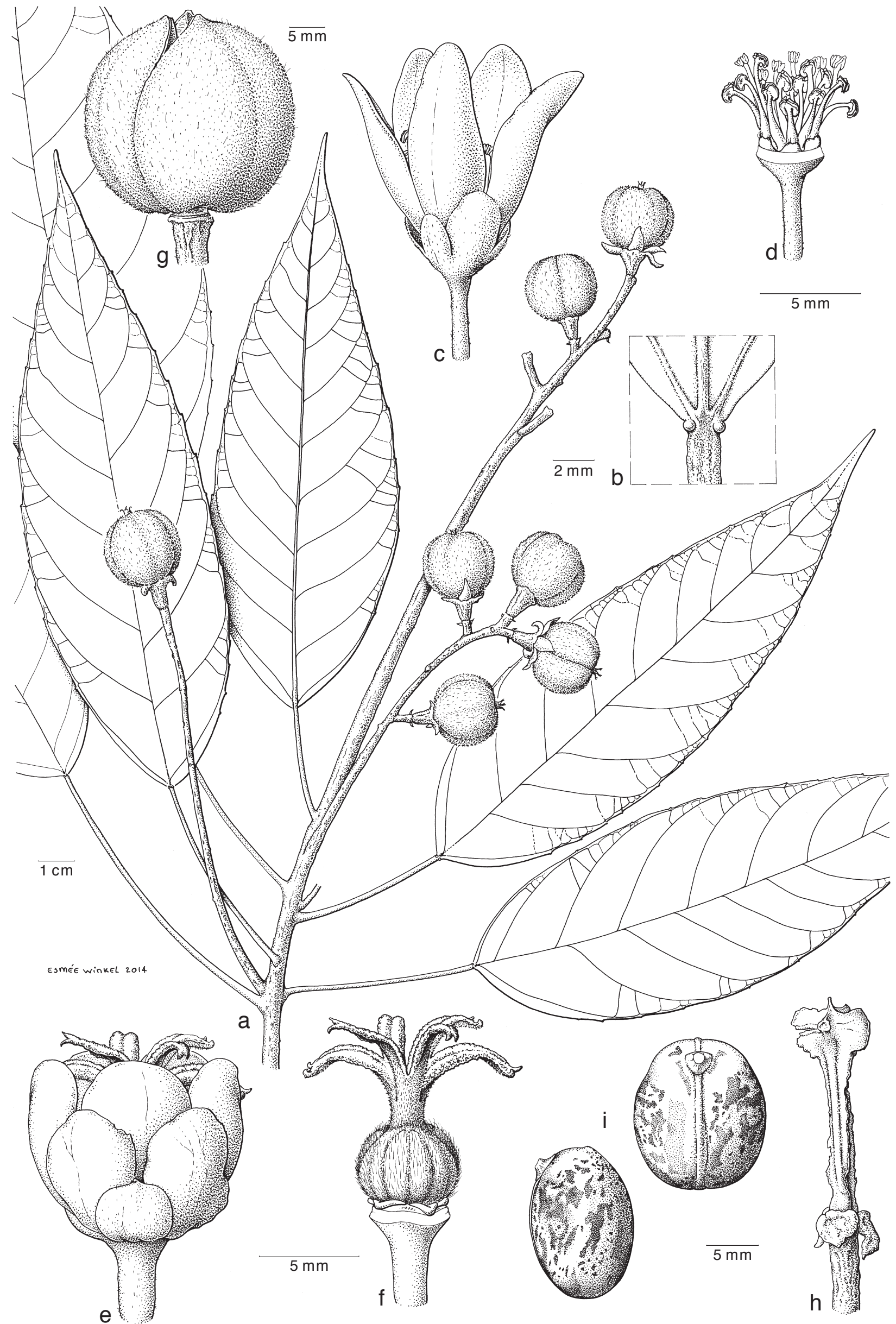

Fig. 1 Ostodes paniculata Blume var. paniculata. a. Habit with infructescences; b. glands at base of leaf blade upper surface; c. staminate flower; d. staminate flower with sepals and petals removed showing disc glands and stamens; e. pistillate flower; f. pistillate flower with sepals and petals removed, showing disc and pistil; g. fruit; h. columella after dehiscence of fruit; i. seed in frontal and side view (a: Geesink et al. 5655A; b, g: Bunchuai \& Nimanong 1406; c, d: Phusomsaeng 407; e, f: Van Beusekom \& Phengklai 170; h, i: Monterie 9; all L). — Drawing: Esmée Winkel, 2014. 
abaxially glandular, lower surface with hair tuft domatia between midrib and secondary nerves and in the main bifurcations of the secondary nerves in the basal part of the blade on Java (absent in northern specimens); venation basally triplinerved, otherwise penninerved, secondary nerves convex near margin, not looped and connecting, third order veins \pm scalariform, higher order veinlets coarsely reticulate. Inflorescences axillary to ramiflorous, paniculate but with short branches in northern specimens when staminate, shorter when pistillate, sometimes a few together, subglabrous to very hairy, staminate ones often flattened; staminate flowers in unorderly cymes per node, pistillate ones single per node; bracts and bracteoles free or basally united, hairy on both sides. Flowers scented; pedicels with subbasal abscission zone, round in transverse section, (sub)glabrous to hairy; calyx 5-lobed, basally united, lobes imbricate, often asymmetric, apices rounded, light green in bud to whitish cream, outside (sub)glabrous to densely shortly hairy, outer lobes smallest and more sepal-like, inner larger, often petallike (especially on Java) but glabrous on inside (compared with petals), upper margin membranous; petals 5 , smaller to larger than inner sepals, free, but often adnate to each other, white (to pink), glabrous except hairy basally on inside, apex round. Staminate flowers: disc glands c. 10, paired, low, thick ridges, radiating from heightened part of receptacle, glabrous; stamens 20-41, white, between disc lobes and inner ones on heightened part of receptacle, outer ones almost or completely free, inner at most basally united, filaments narrowly trapezoid to winged, flat, strongly hairy, white, anthers basi-dorsifixed, elliptic to sagittate, whitish, opening introrse via lengthwise slits, usually bending backward to a horizontal position (then slits pointing upwards), thecae 2, connective dark brown; pistillode absent. Pistillate flowers: disc circular, flat, locally thickened, glabrous; ovary 3-locular, one ovule per locule, densely hairy with short hairs, interspaced with much longer ones, style short, strigose, stigmas basally strigose underneath, above papillate, becoming flatter towards the apex, once or twice bifid. Infructescences pendulous. Fruits usually only one per inflorescence, capsular, yellow greenish to brownish green to brown when fresh, with 6 longitudinal furrows, tardily partly to completely septicidally and partly to completely loculicidally dehiscent into 3 bivalved or 6 cocci, wall drying to a rough surface, with few long hairs, glabrescent, outer wall detaching, inner woody; pedicel thickened and increasing in thickness towards apex; columella basally and apically widened, easily fraying into 2-3 strands. Seeds flattened ovoid to ellipsoid, longitudinally ridged on outside, somewhat triangular on inside, glabrous, smooth, without caruncle. Seedling (text from Gardner s186b1): primary root dull brownish yellow, secondary roots creamy brown, inner tissue pale cream; stem dark creamy brown with darker brown striations and paler brownish cream lenticels near base, otherwise medium green; petioles pale green with creamy brown pulvinae near base in older leaves; blades medium green above, slightly greyish green or yellowish green below, veins on upper surface as lamina, midrib and secondary veins on lower surface pale greenish yellow, tertiary veins dark yellow-green; new leaves pale greenish brown with medium green veins covered with white hairs.

Distribution - Two species, one in China, the other with two varieties, one variety in N Thailand and China, the other in India (Maharashtra, Sikkim, Assam), Myanmar, S China (Yunnan, Hainan), Laos, Thailand, Vietnam, Sumatra, Java.

Note - The plant is always noted as dioecious (e.g., Radcliffe-Smith 2001) and generally there are only flowers of one sex present in a specimen. However, specimens are found with two branches, one with staminate flowers and another, separate branch with fruits. These may come from different plants, but it is also possible that the different sexes appear on the same plant, but separated in time (dichogamous), whereby the staminate and fruit stage overlap. Another indication for this idea is that in O. paniculata var. katharinae the staminate flowers are always present among the new leaves, and the pistillate flowers among the older leaves. Field observations are needed to clarify the matter.

\section{Ostodes paniculata Blume var. paniculata - Fig. 1; Map 1}

Ostodes paniculata Blume (1825) 620; Baill. (1858) 391; Miq. (1859) 384; Müll.Arg. (1866) 1115; Kurz (1877) 404; Hook.f. (1887) 400; Pax in Pax \& Hoffmann (1911) 20; Gagnep. (1925) 322; Backer \& Bakh.f. (1963) 493; Airy Shaw (1967) 411; (1972) 311; (1981) 335; Y.T.Chang (1982) 224; Phattar. \& Chayam. (2007) 461, PI. XXIII: 3. - Ostodes paniculata Blume var. paniculata: Phattar. \& Chayam. (2007) 461, f. 49. - Lectotype (designated here): Blume s.n., s.d., barcode L0158580 (L), [Indonesia,] Java, Mt Salak. Ostodes corniculata Zoll. \& Moritzi ex Baill. (1858) 391. - Type: Cat. Zoll. \& Mor. $471=$ Zollinger 471 ? (n.v.).

Ostodes kerrii Craib (1911) 464; Pax \& K.Hoffm. (1912) 126; Airy Shaw (1967) 411. - Syntypes: Kerr 1091 (K, 2 sheets), Kerr 1432 (K, 2 sheets), Kerr 1719 (K, 2 sheets), Siam (= Thailand), Chiang Mai, Doi Sootep.

Ostodes prainii Gand. (1919) 287. —Type: Prain \& Hock 933 (holo K n.v.), India, Assam, Jaboocka.

Shrubs to trees, to $16 \mathrm{~m}$ high, dbh to $40 \mathrm{~cm}$; flowering branches 4-13 mm thick, bark whitish to greyish brown to brown. Outer bark thin, rough to very finely roughened to pustular lenticellate to smooth, grey to brown; inner bark light to dirty yellow, c. $1 \mathrm{~cm}$ thick; latex thin, red (to yellowish red); sapwood yellow-white. Stipules ovate to ovate-elliptic, $1-1.6$ by $0.5-1 \mathrm{~mm}$, outside somewhat sericeous, otherwise glabrous. Leaves: petiole 1.5$25 \mathrm{~cm}$ long, \pm round in transverse section, near apex with adaxial furrow to slightly channelled, (sub)glabrous; blade ovate to ovate-elliptic, $4.5-29.5$ by $2.2-12.5 \mathrm{~cm}, 1.5-3(-4)$ times as long as wide, base slightly emarginate to rounded to widely acute, margin flat to somewhat recurved, teeth 7-14 mm apart, apex acuminate to cuspidate, both surfaces smooth, upper surface dull dark green, glabrous, lower surface light green, hairy when young, glabrescent; venation slightly raised on both sides (no domatia) to flat above and raised below (domatia present), nerves 8-10 per side. Inflorescences up to $33 \mathrm{~cm}$ long, subglabrous, green; bracts ovate to long triangular, up to 3.7 by $1 \mathrm{~mm}$, margins sometimes basally with a gland-like structure, bracteoles broadly triangular, up to 1 by $1.3 \mathrm{~mm}$. Staminate flowers $8.3-17.5 \mathrm{~mm}$ diam; pedicel $4.8-13 \mathrm{~mm}$ long from abscission zone; calyx: outer lobes ovate, 3.3-7.3 by $2.5-6 \mathrm{~mm}$, inner lobes ovate to obovate, petal-like in W Malesia, $4.2-6$ by $3.2-6 \mathrm{~mm}$; petals 5 , elliptic to oblong, 4.3-10 by $3.8-6 \mathrm{~mm}$; filaments $3.3-4.7 \mathrm{~mm}$ long, anthers $0.6-1.2$ by 0.6-1 mm. Pistillate flowers $11.2-13 \mathrm{~mm}$ diam; pedicel 7-14 $\mathrm{mm}$ long from abscission zone; calyx: outer lobes smaller, triangular, c. $2-4.5$ by $5.5-7.5 \mathrm{~mm}$, inner larger, more obovoid or apically split, c. $4.5-8$ by $6-8 \mathrm{~mm}$ (see note 2 ); petals 5 , ovate to elliptic, $5-8.5$ by $5-7.5 \mathrm{~mm}$; ovary ovoid, $2-4$ by $2-4 \mathrm{~mm}$, yellowish green to red, hairs (especially long ones) caducous, style $0.5-1$ (-5 in fruit) $\mathrm{mm}$ long, stigmas $2.5-4$ (-5 in fruit) $\mathrm{mm}$ long, apex 1-2 mm long. Fruits ellipsoid to obovoid, 3-lobed, $2.2-3.5 \mathrm{~cm}$ high by $1.9-2.8 \mathrm{~cm}$ wide, inner wall $2(-4.5) \mathrm{mm}$ thick; pedicel up to $16 \mathrm{~mm}$ long; columella $1.6-2.9 \mathrm{~cm}$ long. Seeds $1.1-1.7$ by $1.1-1.5$ by $0.9-1.4 \mathrm{~cm}$, not marbled in $\mathrm{N}$ Thailand to marbled in Java.

Distribution - India (Maharashtra, Sikkim, Assam), Myanmar, S China (Yunnan, Hainan), Laos, Thailand, Vietnam, Sumatra, Java; seemingly absent from Cambodia and Peninsular Malaysia.

Habitat \& Ecology - Shaded understorey of primary rainforest, evergreen forest to secondary forest, often with much bamboo, along rivulets, 330-2500 m. Bedrock: granite, limestone. Flowering: February to April, July, October, November; fruiting: January, April to December. 


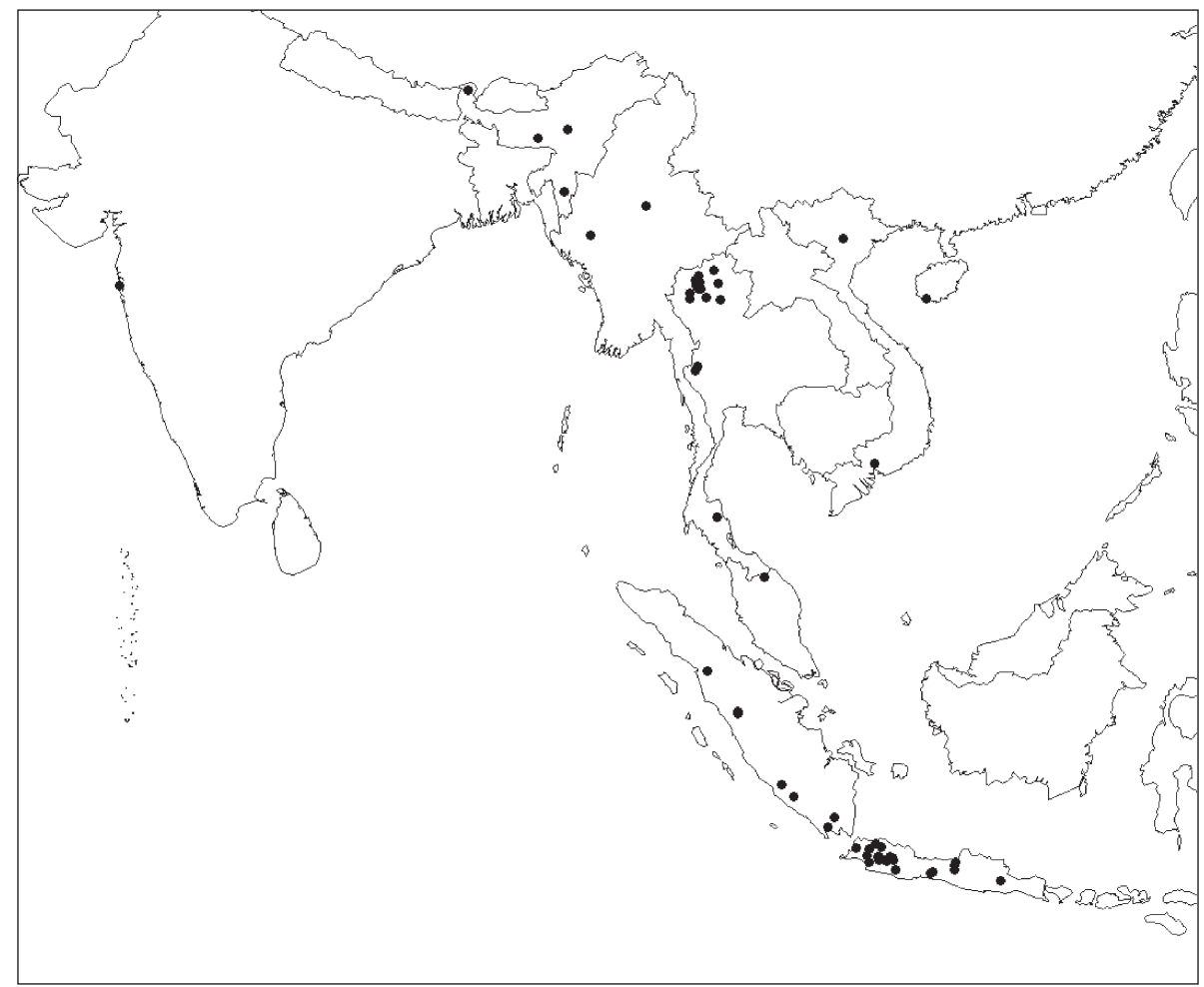

Map 1 Distribution of Ostodes paniculata Blume var. paniculata. Not all specimens in Indochina and India could be georeferenced and are lacking.

Vernacular names - Sumatra: Medang pergam. Java: Gintung, Kaliki moengkim, Kamatakkiang, Kei djahe, Kidjarak, Ki Krantunnang, Ki-momuntjangan, Kirendang, Kirendong (Blume 1825), Kitanglan, Kitoengkoe, Krantunnang, Tankoroh, Walang.

Notes -1 . There is quite some variation, Table 1 shows the major geoclines in characters between $\mathrm{N}$ Thailand and Java.

2. There are several disjunctions (Map 1), the species is unknown for the Malay Peninsula and for the greater part of Thailand (mainly present in $\mathrm{N}$ Thailand and a few specimens from $S$ and SW Thailand). However, these disjunctions do not provide a real gap in the variation that can be used to discern different entities. The disjunctions in Map 1 for Indochina is due to specimens that could not be georeferenced and the status of the W Indian (Maharashtra) specimen is unclear, the label could be incorrect.

3. Radcliffe-Smith (2001) regarded the inner sepals of the pistillate flowers as petals. They appear indeed petal-like, but unlike the petals they lack basal hairs on the inside.

4. Junghuhn s.n. (L 0158629) has an inflorescence that turned into a witches' broom.

Table 1 Major clines in characters between northern specimens (e.g. IndiaIndochina) and W Malesian specimens.

\begin{tabular}{|c|c|c|}
\hline Character & Northern collections & W Malesian collections \\
\hline Glands on apex of pedicel & usually absent, sessile & $\begin{array}{l}\text { present, usually pedi- } \\
\text { celled }\end{array}$ \\
\hline Basal leaf blade glands & sessile & usually pedicelled \\
\hline Leaf blade margin & serrulate & coarsely serrate \\
\hline Leaf blades & slender & broader \\
\hline Leaf venation & hardly raised & raised \\
\hline Domatia & absent & hair domatia \\
\hline Panicles & $\begin{array}{l}\text { more racemiform } \\
\text { (short branches) }\end{array}$ & $\begin{array}{l}\text { more paniculate } \\
\text { (longer branches) }\end{array}$ \\
\hline Inner sepals & sepal-like & petal-like \\
\hline Sepal hairiness & dense & far less dense \\
\hline Seeds & not marbled & marbled \\
\hline
\end{tabular}

\section{NOMENCLATURE OF OTHER SPECIES OR VARIETIES}

\section{Ostodes kuangii Y.T.Chang}

Ostodes kuangii Y.T.Chang (1982) 224. - Type: C.W. Wang 78509 (FJSI n.v.), China, Yunnan, Menghai (paratypes: C.W. Wang 77391, idem; P.Y. Mao 7198, idem; n.v.).

Note - Described as a new species by Chang (1982) because of the dense indumentum. It may be a distinct species, but it may also be part of a geocline, starting in $N$ Thailand $(O$. paniculata var. katharinae) with more hairy specimens and then it may better be regarded as a variety or a synonym.

Ostodes paniculata Blume var. katharinae (Pax) Chakrab. \& N.P.Balakr.

Ostodes paniculata Blume var. katharinae (Pax) Chakrab. \& N.P.Balakr. (1985, publ. 1987) 260; Phattar. \& Chayam. (2007) 463. - Ostodes katharinae Pax in Pax \& Hoffmann (1911) 19; Airy Shaw (1967) 411; (1972) 311; Y.T.Chang (1982) 224. - Syntypes: Henry 13003, 13062, 13549 (K), China, Yunnan, Szemao.

Ostodes thyrsantha Pax in Pax \& Hoffmann (1911) 18 ('thyrsanthus'); Airy Shaw (1967) 412. - Ostodes paniculata Blume var. thyrsantha (Pax) Chakarb. \& N.P.Balakr. (1985, publ. 1987) 260. - Type: Henry 11762D (K), China, Yunnan, Szemao (synonymy according to Chang 1982: 224).

Note - See note under O. kuangii.

\section{EXCLUDED NAMES}

Ostodes angustifolia Merr. (1912) 403. - Type: FB (Whitford \& Hutchinson) 9343 (n.v.), Philippines, Mindanao, district of Zamboanga, Port Banga. $=$ Dimorphocalyx angustifolius (Merr.) Airy Shaw.

Ostodes appendiculata Hook.f. (1887) 401; Pax in Pax \& Hoffmann (1911) 21. — Lepisanthes kunstleri King (1896) 427 , nom. illeg. superfl. - Lepisanthes appendiculata (Hook.f.) Symington (1937) 320; Airy Shaw (1967) 411. - Type: King's collector 4634 (K), [Malaysia,] Perak, Laru = Lepisanthes tetraphylla (Vahl) Radlk. (Sapindaceae) (see Leenhouts (1994) 632). 
Fahrenheitia collina Rchb.f. \& Zoll. in Zollinger (1856) 599; Baill. (1858) 652 ('Fareinhetia'), Müll.Arg. (1866) 1256. — Ostodes collina (Rchb.f. \& Zoll.) Pax in Pax \& Hoffmann (1911) 21 ('collinus'). - Type: Zollinger s.n., Oct. 1856 (n.v.), [Indonesia,] Babi Island, near Djembrana = Paracroton pendulus (Hassk.) Miq.

Ostodes helferi Müll.Arg. (1865) 215; (1866) 1115; Kurz (1877) 404. - Type: Helfer 132 (holo G-DC), Indiae orientalis [Myanmar], prope Maulmain [Moulmein] = Popowia sp. (aff. $\boldsymbol{P}$. pauciflorae Hook.f. \& Thomson, Annonaceae) (see Airy Shaw 1967: 411).

Ostodes integrifolia Airy Shaw (1963) 362 ('integrifolius'). Fahrenheitia integrifolia (Airy Shaw) Airy Shaw (1967) 410. - Type: Lawson 65 (holo K; iso MH), India, Tamil Nadu, Nilgiri Dist., Devala $=$ Paracroton integrifolius (Airy Shaw) N.P.Balakr. \& Chakrab.

Ostodes ixoroides C.B.Rob. (1911) 332. - Type: FB (Klemme) 13426 (iso US), Philippines, Luzon, Province of Ilocos Norte, Bangui $=$ Dimorphocalyx ixoroides (C.B.Rob.) Airy Shaw.

Tritaxis macrophylla Müll.Arg. (1864) 482. - Trigonostemon macrophyllus (Müll.Arg.) Müll.Arg. (1865) 213. — Ostodes macrophylla (Müll.Arg.) Benth. ex Pax \& K.Hoffm. (1911) 18 ('macrophyllus'); Merr. (1912) 404. - Type: Griffith KD 4788 (K), [Malaysia,] Malacca $=$ Paracroton pendulus (Hassk.) Miq.

Desmostemon zeylanicus Thwaites var. minor Thwaites (1861) 278. - Ostodes minor (Thwaites) Müll.Arg. (1865) 214. — Ostodes zeylanica (Thwaites) Müll.Arg. var. minor (Thwaites) Bedd. (1872) t. 274. - Type: Thwaites CP 2158 (CAL, MH), Ceylon [= Sri Lanka], Central Prov. = Paracroton zeylanicus (Müll.Arg.) N.P.Balakr. \& Chakrab.

Ostodes muricata Hook.f. (1887) 401. - Ostodes muricata Hook.f. var. genuina Pax in Pax \& Hoffmann (1911) 21, nom. inval. - Type: King's collector s.n. (holo K; iso P? King's collector 6612), [Malaysia,] Perak, Larut = Dimorphocalyx muricatus (Hook.f.) Airy Shaw.

Ostodes muricata Hook.f. var. ?minor Hook.f. (1887) 401. Lectotype (see Van Welzen \& Van Oostrum 2015): Lobb 304 (holo ; iso E, GH, 2 sheets), Singapore = Dimorphocalyx muricatus (Hook.f.) Airy Shaw.

Ostodes pauciflora Merr. (1916) 72 ('pauciflorus'). - Type: Hose 244 (iso A, L, P), Malaysia, Sarawak, Baram District, Baram $=$ Dimorphocalyx pauciflorus (Merr.) Airy Shaw.

Croton pendulus Hassk. (1848) 266. _ Ostodes pendula (Hassk.) A.Meeuse (1943) 109. - Fahrenheitia pendula (Hassk.) Airy Shaw (1967) 410. - Type: Unknown (?), Java, Prov. Bandung $=$ Paracroton pendulus (Hassk.) Miq.

Ostodes serratocrenata Merr. (1909) 283. - Syntypes: FB (Klemme) 7078 (n.v.), Philippines, Luzon, Cagayan Prov., San Vicente; FB 11271 (n.v.), Philippines, Luzon, Cagayan Prov., Aparre $=$ Paracroton pendulus (Hassk.) Miq.

Ostodes villamilii Merr. (1917) 92. - Type: Villamil 164 (PNH, burnt; K?, US?), [Malaysia, Sabah,] British North Borneo, Sandakan $=$ Tapoides villamilii (Merr.) Airy Shaw.

Desmostemon zeylanicus Thwaites (1861) 278. - Ostodes zeylanica (Thwaites) Müll.Arg. (1865) 214. - Fahrenheitia zeylanica (Thwaites) Airy Shaw (1967) 410. - Type: Thwaites CP 2160 (CAL, G-DC, K), Ceylon (= Sri Lanka), Central Prov. $=$ Paracroton pendulus (Hassk.) Miq. subsp. zeylanicus (Thwaites) N.P.Balakr. \& Chakrab.

\section{REFERENCES}

Airy Shaw HK. 1963. XLI. An overlooked Ostodes from South India. Notes on Malaysian and other Asiatic Euphorbiaceae. Kew Bulletin 16: 341-372. Airy Shaw HK. 1967. Notes on Malaysian and other Asiatic Euphorbiaceae. LXXIX. Realignments in the Ostodes-Dimorphocalyx complex. Kew Bulletin 20: 379-416.

Airy Shaw HK. 1972. The Euphorbiaceae of Siam. Kew Bulletin 26: 191-363. Airy Shaw HK. 1981. The Euphorbiaceae of Sumatra. Kew Bulletin 36: 239 374.

Backer CA, Bakhuizen van den Brink Jr RC. 1963. Flora of Java 1. Noordhoff, Groningen.

Baillon MH. 1858. Étude générale du groupe des Euphorbiacées. Masson, Paris.

Balakrishnan NP, Chakrabarty T. 1993. The genus Paracroton (Euphorbiaceae) in the Indian subcontinent. Kew Bulletin 48: 715-726.

Beddome RH. 1872. The Flora Sylvatica for Southern India. Gantz Brothers, Madras.

Bentham G. 1880. Euphorbiaceae. In: Bentham G, Hooker JD (eds), Genera plantarum 3: 239-340. Reeve \& Co., London.

Blume CL. 1825. Bijdragen tot de Flora van Nederlandsch Indië 12. Lands Drukkerij, Batavia.

Chakrabarty T, Balakrishnan NP. 1985 (publ. 1987). A note on the genus Ostodes (Euphorbiaceae). Bulletin of the Botanical Survey of India 26: 259, 260

Chang YT. 1982. Materiae ad Floram Euphorbiacearum Sinensium I. Acta Phytotaxonomica Sinica 20: 224, 225.

Craib WG. 1911. LIII-Contributions to the Flora of Siam. Bulletin of Miscellaneous Information, Kew: 384-474.

Gagnepain F. 1925. Euphorbiaceae. In: Lecomte MH (ed), Flore générale de l'Indo-Chine 5. Masson \& Cie., Paris.

Gandoger M. 1919 (publ. 1920). Setum plantarum novarum, pas secunda. Bulletin de la Société Botanique de France 66: 286-307.

Grierson AJC, Long DG. 1987. Flora of Bhutan 1, 3. Royal Botanic Garden, Edinburgh.

Hasskarl JK. 1848. Plantae Javanicae Rariores. Foerstner, Berolini.

Hooker JD. 1887. The Flora of British India 5. Reeve \& Co., London.

King G. 1896. Materials for a Flora of the Malay Peninsula. Journal of the Asiatic Society of Bengal 65, 2: 339-515.

Kurz WS. 1877. Forest Flora of British Burma 2. Office of the Superintendent of Government Printing, Calcutta.

Leenhouts PW. 1994. Lepisanthes. In: Adema FACB, Leenhouts PW, Van Welzen PC (eds), Flora Malesiana series I, 11, 3. Foundation Flora Malesiana, Leiden.

Meeuse ADJ. 1943. Euphorbiaceae. In: Backer CA(ed), Beknopte Flora van Java 4b3, fam. 112. Rijksherbarium, Leiden.

Merrill ED. 1909. New or noteworthy Philippines plants, VII. The Philippine Journal of Science 4, Botany: 247-330.

Merrill ED. 1912. Notes on Philippine Euphorbiaceae. The Philippine Journal of Science 7: 379-410.

Merrill ED. 1916. Notes on the Flora of Borneo. The Philippine Journal of Science 11: 49-77.

Merrill ED. 1917. Contributions to our knowledge of the Flora of Borneo. Journal of the Straits Branch of the Royal Asiatic Society 76: 75-117.

Miquel FAW. 1859. Flora van Nederlandsch Indië 1, 2. Van der Post, Amsterdam.

Müller (Argoviensis) J. 1864. Neue Euphorbiaceen des Herbarium Hooker in Kew. Flora 47: 481-487.

Müller (Argoviensis) J. 1865. Euphorbiaceae. Linnaea 34: 1-224.

Müller (Argoviensis) J. 1866. Euphorbiaceae. In: De Candolle AP (ed), Prodromus Systematis Naturalis Regni Vegetabilis 15, 2. Masson \& Filii, Parisiis.

Pax F, Hoffmann K. 1911. Euphorbiaceae-Cluytieae. In: Engler A (ed), Das Pflanzenreich IV.147.iii. Engelmann, Leipzig.

Pax F, Hoffmann K. 1912. Euphorbiaceae-Acalypheae-Chrozophorinae. In: Engler A (ed), Das Pflanzenreich IV.147.vi. Engelmann, Leipzig.

Pax F, Hoffmann K. 1931. Euphorbiaceae. In: Engler A, Harms H (eds), Die natürlichen Pflanzenfamilien ed. 2, 19C. Engelmann, Leipzig.

Phattarahirankanok K, Chayamarit K. 2007. Ostodes. In: Van Welzen PC, Chayamarit K (eds), Euphorbiaceae. In: Santisuk T, Larsen K (eds), Flora of Thailand 8, 2. The Forest Herbarium, Bangkok.

Radcliffe-Smith A. 2001. Genera Euphorbiacearum. Royal Botanic Gardens, Kew.

Robinson CB. 1911. Alabastra Philippinensia, III. The Philippine Journal of Science, C. Botany 6: 319-358.

Symington CF. 1937. XXVIII-Imperfectly known species misplaced in the Flora of the Malay Peninsula. Bulletin of Miscellaneous Information, Kew: $318-320$. 
Thwaites GHK. 1861. Enumeratio Plantarum Zeylaniae. Dulau \& Co., London. Van Welzen PC, Van Oostrum AF. 2015. Revision of the Malesian species of Dimorphocalyx (Euphorbiaceae). Blumea 59: 191-201.

Webster GL. 1994. Synopsis of the genera and suprageneric taxa of Euphorbiaceae. Annals of the Missouri Botanical Garden 81: 33-144.

Zollinger H. 1856. Anmerkungen zu den "Rottlera-arten des botanischen Gartens zu Buitenzorg” u.s.w. Linnaea 28: 598-600.

\section{IDENTIFICATION LIST}

Only specimens with a collector name and number are included in this list.

1 = Ostodes paniculata var. katharinae

2 = Ostodes paniculata var. paniculata

Afriastini 2532: 2.

Backer 23035: 2 - Balansa 2384: 2; 3248: 2 - Blume 1484: 2 - Bunchuai \& Nimanong 1406: 2 - Bünnemeijer 3825: 2.

Chand 4498: 2; 6924: 2.

Dickason 7128: 2; 8421: 2

Endert E 1041: 2
Forbes 958: 2; 1042: 2; 2181: 2; 2309: 2 - Fukuoka T-62179: 2.

Gardner s186b1: 2 - Garrett 656: 1; 939: 1 - Geesink, Phanichapol \& Santisuk 5655A: 2 - Griffith KD 4790: 2.

Hochreutiner 708: 2 - Houtsoorten van den Gedeh (Java) 18: 2 - How 70657: 2 .

Ichlas 26: 2

Jacobs 8021: 2.

Kerr 5182: 1; 20984: 2 -Koorders 2591: 2; 2594: 2; 2595: 2; 2596: 2; 2597 2; 2598: 2; 2600: 2; 2602: 2; 2605: 2; 2607: 2; 2608: 2; 13914: 2; 24213: 2; 25628: 2; 25735: 2; 26730: 2; 27733: 2; 32895: 2; 33903: 2; 36036: 2; 36548: 2; 39244: 2 - Kostermans 840: 2 - Koyama T-61171: 2.

Maxwell 87-816: 2; 88-267: 2; 89-230: 2; 89-862: 2; 90-403: 1; 90-458: 2 ; 90-537: 2; 92-290: 2; 93-574: 2; 94-305: 2; 95-406: 2; 95-791: 2; 95-834: 2; 96-444: 2; 96-815: 2; 97-285: 2; 02-268: 2 - Meijer 3310: 2; 3409: 2 Mogea 2550: 2 - Monterie 9: 2.

Phloenchit 1064: 2 - Phusomsaeng 407 (1968): 2 - Poilane 18111: 2 Pooma, Phattarahirankanok, Sirimongkol \& Poopath 3897: 1; 3956: 2.

Santisuk 1495: 2 - Smith, J.J. 477: 2 - Smitinand 90-36: 1 - Sutrisno 97: 2. UNESCO 246: 2.

Van Balgooy \& Wiriadinata 2943: 2 - Van Beusekom \& Phengkhlai 170: 2; 1011: 2.

Winckel 135: 2; 1718: 2; 1828: 2 - Winit 1359: 1 - Wiriadinata 15: 2; $377: 2$. 